\title{
Oral History Interviews with Iowa Women: A Survey of Collections in Iowa
}

\section{BECKY WILSON HAWBAKER}

ORAL HISTORY INTERVIEWS have come to be recognized as an important tool for historical research, especially for women's history. Women's experiences are often hidden or obscured in many of the more traditional historical sources. The potential of oral history to add neglected perspectives to our understanding of the past has led to great optimism and high expectations, especially in the field of women's studies. Researchers in that field have argued that "interviews allow women to speak for themselves, to describe their situation, define their identity, and interpret the meaning of their own lives." Another adds, "When women speak for themselves, they reveal hidden realities that challenge the 'truths' of official accounts and cast doubt upon established theories." Other women's oral history advocates affirm goals beyond historical inquiry. "Women's oral history," says one, "engages us, enlightens us, moves us, because it can forge a connection and build a bridge across generations. . . . Women's oral history can revalue the meaning of women's lives and honor the women who came before us." ${ }^{11}$

Not all oral history projects live up to these expectations. Susan Armitage has drawn a distinction between women's oral

1. Nancy Grey Osterud and Lu Ann Jones, "'If I Must Say So Myself': Oral Histories of Rural Women," Oral History Review 17 (Fall 1989), 2; Kathryn Anderson, Susan Armitage, Dana Jack, and Judith Wittner, "Beginning Where We Are: Feminist Methodology in Oral History," Oral History Review 15 (1987), 104; Frontiers Editorial Board, "Letter to Our Readers," Frontiers 7 (1983), iv.

THE ANNALS OF IOWA 53 (Summer 1994). CThe State Historical Society of Iowa, 1994. 
history and oral history interviews with women. She argues that interviews are most valuable to women's history when they focus on the woman's experiences, choices, and feelings: "Because women live longer, these [local history] collections contain many interviews with women, but they are usually tremendously disappointing. The women talk about the activities of their fathers, brothers, husbands, and sons. They do that because they believe that history was made by men. ... Usually, the interviewers do not contradict them. The result is that most old settler local oral history projects tell us very little about women."

Whether an oral history project answers a particular research question is a moot point if researchers do not know of the project's existence and thus cannot assess the collection's usefulness to their research. There are a growing number of excellent oral history projects in Iowa, ably conducted by volunteers and professionals from local libraries, museums, schools, and historical societies. Unfortunately, there are few finder's aids to direct researchers to local oral history collections, which are scattered about the state, so many of them remain hidden treasures. All too often, this publicity problem is made worse by inaccessibility: interviews are not transcribed, indexed, or catalogued, and are thus "left as useless caches in someone's desk. ${ }^{\prime 3}$ Many oral history collections in Iowa suffer from the accessibility problem, nearly all from the publicity problem. It is hoped that this essay will alleviate the latter, which may in turn revive interest in the former.

The oral history collections described in this essay were located in a number of ways, over the course of a year. ${ }^{4}$ In all

2. Susan H. Armitage, "The Next Step," Frontiers 7 (1983), 3. An expanding literature on the "feminist practice of oral history" expressly addresses this concern. See, for example, Sherna Gluck and Daphne Patai, eds., Women's Words: The Feminist Practice of Oral History (New York, 1990); Anderson, et al., "Beginning Where We Are," 103-27.

3. Frederick J. Stielow, The Management of Oral History Sound Archives (New York, 1986) 2.

4. The search began with Allen Smith's Directory of Oral History Collections (Phoenix, 1988) and the results of two mail surveys of Iowa libraries, one conducted by State Historical Society of lowa (SHSI) archivist Mary Bennett, the other by the Local History Roundtable of the lowa Library Association. Others consulted for additional sources include Loren Horton, SHSI Senior 
but one case, the oral history collections were described to the author by phone or mail, and were not directly examined by the author. The quality of most of the interviews is thus unknown, and is left to researchers to discover for themselves. In addition, it was difficult to determine much of the specific subject matter of the interviews. Undoubtedly, many are not women's oral history by Armitage's definition. In some of the following interviews, for example, women were asked mainly about famous Iowa males they had known, such as regionalist artists Grant Wood and Marvin Cone, or were asked to identify which businesses occupied a particular building over her lifetime. Whatever concerns exist about the quality and accessibility of Iowa's oral history collections, the quantity of available interviews and the range of topics they cover is impressive; and one may assume that all interviews with women are valuable.

SEVERAL ORAL HISTORY PROJECTS are topical in nature. Very few projects focused on women as an organizing topic. One notable exception is a collection of interviews by Suzanne Schenken with forty-five Iowa women state legislators (10-12 additional interviews are complete, but not yet released by the interviewee). This project includes interviews with Democrats and Republicans from both the house and the senate, serving in the legislature as early as 1929 and as late as the present. The interviewees include Elaine Baxter, Joy Corning, Minnette Doderer, and Jo Ann Zimmerman. All interviews are transcribed and indexed. Copies of the transcripts are held by both the Women's Archives at the University of Iowa and the Parks Library at Iowa State University.

Another collection focused expressly on women is "Her Own Story," told by a collection of ten interviews with women

Historian, who has conducted many oral history workshops over the past fifteen years; administrators of each of Iowa's seven Regional Libraries; Jerome Thompson, former president of the Iowa Museum Association; and the Iowa Humanities Board (IHB) publication Muses, which announces winners of IHB grants. Still, this compilation is emphatically preliminary; it is likely that important collections were overlooked. 
conducted by the Benton County Historical Society and the Vinton branch of the American Association of University Women, and sponsored by the Iowa Humanities Board (IHB). All of the interviews are transcribed and include biographical information. The women interviewed include a telephone operator and a nurse. Questions clustered around family background, education, work history, personal memories, and historical events. The collection is housed at the Vinton Public Library, and there is an interlibrary loan copy of the transcripts.

EDUCATION is a topic that has received attention both as the major focus of entire projects and as a standard line of questions in most of the others. Such projects usually include more interviews with women than others because teaching has traditionally been regarded as women's work. Two such projects were sponsored by the IHB. The Red Oak Public Library houses an oral history collection on country schools in Montgomery County. Forty-one interviews with teachers, students, and parents were conducted; 33 of these are with women. Unfortunately, none of the interviews are transcribed. The Prairie Arts Council in Sheldon conducted interviews and gathered written stories on one-room country schools of that area. There are a total of 64 interviews, 41 of which are with women, and 56 written stories, 50 of which are by women. The majority of the interviews are transcribed, and organizers plan to transcribe all of the remaining interviews. The collection is now kept at the Sheldon Public Library, but the Prairie Arts Council hopes to move the collection to a schoolhouse they are renovating.

Several of Iowa's institutions of higher education have employed oral history to record their histories. A number of transcribed interviews with women involved in higher education are thus included in the special collections of both the University of Iowa Libraries and Iowa State University's Parks Library. A 1976 University of Iowa project includes interviews with Lois Boulware of Student Health Services, Helen E. Focht of the Office of the Dean of Students, Susan Hancher describing her husband Virgil's tenure as president, M. Gladys Scott recalling physical education for women, Ruth Updegraff of the Institute 
of Child Behavior and Development, and Pearl Zemlicka of the nursing program. ${ }^{5}$

Iowa State's collection is considerably larger overall (184 interviews) but only ten of the interviews are with women. Both administrators and alumni were interviewed, including Goldie Rouse Buckner, a 1948 alumna who describes her work with individuals with developmental disabilities; Margaret Davidson, a 1929 alumna who was editor of Ladies' Home Journal; Margaret Lange, an administrator from 1933 to 1959 in the area of social life on campus; Madge Irwin McGlade, the first Director of Residence at Iowa State; E. Madge Miller, who taught in the area of food and nutrition; Constance Beardshear Moye, daughter of President William Beardshear and a 1915 alumna, who describes the Iowa State of her youth; Frederica Shattuck, a professor of Public Speaking beginning in 1907; and several others describing the work of their husbands or fathers. All of the interviews are either transcribed or summarized.

SERVICE ORGANIZATIONS and projects are an organizing theme of two projects and a fairly standard line of questioning in many others. The Davenport Public Library was recently awarded funds from IHB to conduct oral history interviews with those who lived or worked at the Annie Wittenmeyer Home (once called the Iowa Soldiers Orphan's Home). The interviews, which organizers plan to transcribe, will be held at the Davenport Public Library.

A different kind of service - military service - is explored in another project in progress. The Wapello County Historical Society, with funding from IHB, will conduct interviews with former servicemen and civilian employees of the Naval Air Station in Ottumwa during World War II, as well as with WAVES (Women Accepted for Volunteer Service). Five WAVES have been interviewed to date, discussing why they volunteered, their duties, their living conditions, and their impressions of Ottumwa. Three female civilians who worked in the station's

5. This project is described in more detail in James Beliman, "The University of Iowa Oral History Project," Books at Iowa 27 (November 1977), 21-29. 
offices or laundry facility have been interviewed as well. The interviews, which are being transcribed, will be housed at the Wapello County Museum.

RACE OR ETHNICITY is the focus of several oral history collections, and the interviewee's ethnic heritage was another standard line of questions in many other interviews. These interviews demonstrate surprising diversity. One ongoing crosscultural and multi-generational project sponsored by IHB involves students of the Talented and Gifted Program at South Tama High School interviewing small groups of Mesquakie Elders. Three women have been interviewed, including Adeline Wanatee, who was recently inducted into the Iowa Commission on the Status of Women's Hall of Fame. The transcribed interviews are now held at the South Tama High School library, and copies are planned for the South Tama Public Library.

A project jointly sponsored by the IHB and Grand View College examines the life histories of twenty Arab Americans living in central Iowa, eight of whom are women. Interviewees include descendants of early immigrants as well as more recent immigrants, with ancestral roots in present day Lebanon, Syria, Iraq, Palestine/Israel, and Egypt, of both Christian and Muslim religious traditions. Women discussed topics such as religion, education, growing up, occupations, marriage, the decision to emigrate, visiting the old country, food, and-occasionallywomen's roles. All of the interviews are transcribed and are held at the Grand View College Library. Transcripts are available in booklet form from project director Lee Tesdell. ${ }^{6}$

The Toldot Iowa Jewish Oral History Collection at Grinnell College is a product of the Iowa Jewish Heritage Project sponsored by the Jewish Federation of Greater Des Moines and the State Historical Society of Iowa. Seventy-nine of the 121 interviewees are women, who talked about what it was like to grow

6. Lee Tesdell, Grand View College, 1200 Grandview Ave., Des Moines, IA 50315. The cost of the booklet, "The Way We Were: Arab-Americans in Central Iowa," is $\$ 6.00$, and checks should be made out to the Grand View College business office. 
up Jewish in Iowa, and about the creation of a Jewish community life in small towns as well as urban centers in Iowa. About half of the interviews are transcribed.?

African-American Iowans are the focus of two projects. The Nodaway Valley Historical Society in Clarinda videotaped interviews with more than 60 African Americans, including 22 women. Those interviewed include June Franklin, an Iowa legislator; a lawyer; a World War II-era Pentagon secretary; a dancer; and several secretaries, dressmakers, and homemakers. The interviews are not transcribed. The Silos and Smokestacks Oral History Project in Waterloo has begun to gather oral history interviews of African Americans as resources for the proposed National Park. So far, though, only three African-American women have been interviewed. The interviews will be housed at the Henry W. Grout Museum of History and Natural Science in Waterloo.

One African-American woman and several Latino and German women have been interviewed as part of an oral history project titled "Front Street to Highway 61" conducted by the Fort Madison Public Library and sponsored by IHB. This project, still in progress, focuses on three ethnic groups in turn-of-thecentury Fort Madison: African Americans, Latinos, and Germans. Project organizers hope to complete 20-25 interviews and plan to transcribe all interviews and compile parts of the interviews into a slide presentation. The interviews will be held at the Fort Madison Cattermole Public Library.

Another project still in progress will focus on Italian immigrants in the Des Moines area. The Italian American Cultural Center in Des Moines has received funding from IHB for its project, "I Figli d'Italia - The Children of Italy." Organizers project at least 25 transcribed interviews and pictures, to be housed at the Cultural Center.

The Amana Heritage Society undertook an extensive oral history project, interviewing all residents who were at least 18 at the time of the Communal Change in 1932. Of the 150 inter-

7. To read portions of a few of the interviews integrated into an interpretive survey of the Jewish experience in Iowa, see Michael J. Bell, "True Israelites of America': The Story of the Jews of Iowa," Annals of Iowa 53 (1994), 117-21. 
views conducted, many of which were with women, 90 were transcribed. Topics include the Amana Society, courtship, marriage, childbirth, religion, holidays, schools, housing arrangements, communal kitchens, the bakery, the 1932 Change, and many others. Nearly all of the interviews are in English, but a working knowledge of German is recommended in working with them. The project is held at the Amana Heritage Research Library, and its use is by appointment only.

The Danish Immigrant Museum in Elk Horn has collected a number of oral history interviews with midwestern Danish women. Seven women were interviewed by a graduate student from Denmark, who asked about the decision to emigrate to America, family, Danish identity, religion, politics, and education. Steven Ohrn and a student from Northwest Missouri State University asked nine women about continuing Danish traditions in crafts, foodways, and music. Folklorist Greg Hansen conducted another project on Danish craft traditions, interviewing six women, some of whom demonstrate their crafts at Tivoli Fest in Elk Horn. The most recent - and largest - project, supported by IHB, includes 35 women interviewed about "The Danish Immigrant Experience." Interviewers in this project asked about family life and daily routines in Denmark, the decision to emigrate, the journey to America, and the assimilation process. None of the interviews are fully transcribed, but biographical information, an interview summary, and a running subject log accompany most tapes.

Another interesting project examined a different kind of immigrant - "immigrants from within." The University of Iowa Affiliated Program and IHB sponsored an oral history project interviewing individuals with mental disabilities who had spent part or all of their childhood in Iowa's state hospital schools at Woodward or Glenwood. The interviews focused on their transition to more independent living arrangements. The four women interviewed describe their placement in the institution, their life there, how they left, and their life in the community. Transcripts are available from the University of Iowa Hospital Schools Clearinghouse (1-800-272-7713). 
WOMEN'S EMPLOYMENT is another topic around which entire projects are organized and one that is often at least touched on in more eclectic interviews. The largest collection of labor history oral interviews in the state - and one of the largest in the nation - numbers over one thousand interviews and is held by the State Historical Society of Iowa in Iowa City. Many of the interviews in the Iowa Labor History Oral Project are with women. The collection covers all of the industrial cities in the state and the entire range of unionized trades and industries. About 90 percent of the interviews are transcribed. ${ }^{8}$

Several local oral history projects focus on working people. The Research Center for Dubuque Area History at Loras College houses the only set of oral history interviews focusing exclusively on working women. They were conducted by Mary Allison Farley for her University of Iowa master's thesis on wageearning women in Dubuque, 1910-1917.' Twenty-two women were interviewed, four anonymously. The Laurens Public Library is now conducting an oral history project interviewing people from local industries. The project will include interviews with women "egg breakers" from Scrivener's food wholesalers and women in management positions. The Putnam Museum in Davenport has a small collection of oral history interviews conducted to provide context for donated manuscripts and objects associated with the Eagle Sign Company. Two women were interviewed: the daughter of the founder, and a secretary. And the Silos and Smokestacks Oral History Project mentioned earlier is interviewing women about Waterloo's industrial and agricultural heritage. Ten to twenty interviews are planned.

Women whose careers were in the arts are interviewed in two projects. The Midwest Old Thresher's Museum of Repertoire Americana in Mount Pleasant houses a collection of 40 videotaped interviews with individuals, including some women,

8. Shelton Stromquist drew on many of these interviews to compile Solidarity and Survival: An Oral History of Iowa Labor in the Twentieth Century (Iowa City, 1993). The appendix lists all of the interviewees by city.

9. Mary Allison Farley, "Wage-Earning Women in Dubuque, Iowa, 1910-1917: Their Position in the Labor Force and How They Remember That Experience" (M.A. thesis, University of Iowa, 1985). 
who traveled with the Tent, Folk, and Repertory Theater players in the years 1900-1940. The interviews are organized by the year they were taped rather than by subject or names, and they are not transcribed. For its "Music in the Quad Cities" oral history project, the Putnam Museum in Davenport interviewed women who described a family-owned music store, the June Jamboree country music festival, music education, sacred music, area music clubs, the Quad City Symphony, and the musical heritage of Navajo, Mesquakie, African-American, Belgian, and Irish residents. All of the interviews are transcribed and include a biographical sketch and interview abstract.

OTHER ORAL HISTORY PROJECTS are not easy to classify. Whether large or small, they include interviews with a variety of people on a wide range of topics. The largest oral history collection in the state is housed at the State Historical Society of Iowa in Iowa City. In addition to the 1,000 labor history interviews mentioned earlier, the collection includes 406 interviews with women on a variety of topics. Most notable are 192 "Voices of American Homemakers" interviews and 44 interviews with century farm owners discussing issues related to farm women's lives, from land transfers to charivaris. Both sets of interviews are thoroughly catalogued, indicating the specific topics addressed by each interviewee. Other interviews by University of Iowa students taking courses in Iowa history, women's history, and music history cover topics such as prohibition and bootlegging, the Great Depression, women on the Iowa homefront during World War II, family and local history, courtship and marriage, entertainment and social life, and women's roles on the farm.

Most of the remaining projects focus on a particular place, namely the community that conducts the interviews. Generally, these projects are about growing up in the local area, usually in the first half of the twentieth century. Researchers should not overlook such collections, even if they appear unpromising: a project that one librarian described as "just general reminiscing stuff" contained a number of interviews with women on important topics; such as their ethnic identity, employment options, and family decisions. 
Some of these local collections are organized around historical events or specific periods of time. Often, the era seems to be chosen by default. That is, the time period is chosen because it represented the childhood and adolescent years of the oldest people in town. It is rare to find a collection that interviews younger people about more recent events. It is true that there is more of an imperative to collect the stories of older Iowans before death can erase them. However, time also can erase or distort memories, so it would be wise to begin to record the impressions of younger people and more recent events. ${ }^{10}$

The Research Center for Dubuque Area History holds a collection of interviews on the New Deal era, recorded by Loras College history students. Twenty women were interviewed, including a librarian, two nuns, and several farm women. None of the interviews are transcribed. The Perry Public Library conducted an oral history project as part of its IHB discussion series, "Time Slice III: 1914-1945." Of six interviews, three are with women, one of whom talks about nearly losing the family farm during the Great Depression. None of the interviews are transcribed. Another project that grew out of the Time Slice series is located at the Stewart Library in Grinnell. Twenty people were interviewed for "Grinnell's Voices from the Past: The Depression and World War II Oral History Project." These included nine women, who answered questions about family, leisure, family economics, New Deal programs, general attitudes, education, public affairs, and military services. A project conducted by the Pocahontas Public Library focuses mainly on the town itself in the 1920s and 1930s. Of the 10 transcribed interviews, 3 are with women, one who played the piano for the silent movie house, another who was an attorney, and another who discussed the social life in town. In addition, interviewers were instructed to ask everyone they interviewed about women's roles during their lifetimes.

Other collections of local oral history interviews cover a broader range of time and events. The largest such collection

10. One interesting project, now unfortunately on hold, was unusual in that Muscatine high school students were interviewed. These students were recent immigrants from Latin America, and the project will focus on their transition. 
is held by the Sioux City Public Museum. It includes 500 interviews, most of which are transcribed and individually and collectively indexed. Approximately 180 interviews with women are included in this collection. Among the topics discussed are education, including memories of Central High; employment as authors, nurses, teachers, seamstresses, telephone operators, and others; family; politics; crime and criminals; urban renewal; real estate and construction; churches and religious organizations; women's clubs and service organizations; steamboats, streetcars, and other forms of transportation; a polio epidemic; the Sioux City College of Medicine; Billy Sunday in Sioux City; the Community House's work with immigrants; Peace Corps service; Morningside College; Sioux City businesses such as Sheffield's Bad Instruments and Repair, Ye Olde Tavern Restaurant, and Ferris Flower Shop; recreational activities, such as going to the Peavey Opera House, quilting, and the Queen of River-Cade contest; and many more.

The Cedar Falls Historical Society possesses more than 200 interviews conducted as part of several projects, including one, "Readin' Ritin' and Reminiscin'," that records memories of area one-room country schools. The interviews are transcribed, and there is a short description of one broad interview topic for each interview. Women interviewed include a milliner, a German teacher and early advocate of woman's rights, several WAVE officers stationed in Cedar Falls during World War II, several who describe ice cutting, and several Danish women discussing their ethnic heritage.

The Musser Public Library in Muscatine holds a collection of 125 oral history interviews. Ten women were interviewed along with their husbands, 5 women are interviewed with other women, and 34 women were interviewed alone. The women talked about their jobs as teachers, nurses, businesswomen, factory workers, a mail carrier, and a department store buyer. They also discussed neighborhoods, community service, their families, and their churches. None of the interviews are transcribed.

Transportation was to be the emphasized topic in 100 transcribed oral history interviews, 51 of them with women, conducted by the Rolfe Public Library and sponsored by IHB. 
Although all of the interviews do include transportation as a line of questions, interviews were not limited to that topic. Topics include the family's first car and who learned to drive it, taking the train, walking or taking a bus to school, as well as homefront activities during the two world wars, listening to radio shows, family dynamics, gender roles, and teaching in the 1950s. One of the women interviewed described her activities in the late 1970s at Rolfe's high school (including basketball, being chosen band queen, and getting TP'd) and her transition to Iowa State University (including choice of a major, co-ed dorm life, and being a fraternity "little sis.")

Approximately 90 oral history interviews are held by the Sioux Center Public Library. Twenty-two of these are women interviewed with their husbands, and 19 are with women alone. None of the interviews are transcribed. Topics varied from interview to interview, but common questions centered on living conditions, economic conditions, farming, housekeeping, town controversies (such as whether Sioux Center should have a movie theater), local politics, immigration, historical events and their local ramifications (such as reaction to legislation outlawing the use of the German language during World War I). Project director Mike Vanden Bosch explained, "There were many stories of personal tragedy and of how people responded to it."11

Computer technology has improved the accessibility of a few oral history collections to date, and promises to increase access to a greater extent in the future. Names of interviewees and topics discussed can be searched and perused on-line from both the Des Moines and Cedar Rapids Public Library. Both libraries have catalogued their oral history collections on their computer catalogue systems. The Des Moines Public Library collection consists of 82 transcribed interviews, including 31 women. The interviews with women include Louise Noun discussing the ICLU and ACLU; United Way head Marguerite Esters Cothorn addressing civil rights in Des Moines; Julia Mayer describing her work at the Jewish Community Center; Bonnie Percival talking about the Percival Art Gallery; Florence

11. Mike Vanden Bosch, undated correspondence received 19 January 1993. 
Meyer, Iowa's first woman stockbroker; and topics such as immigration, the Holocaust, surviving the Titanic, women in Des Moines government, flappers, the South Dakota gold rush, the history of community institutions such as the Art Center, the Public Library, the Community Playhouse, and Drake University, plus many more.

The Junior League of Cedar Rapids conducted the oral history interviews held by the Cedar Rapids Public Library. The library's computer system, INDEX (Information Network for Discovery and EXploration) lists 86 interviews, 37 of which are with women. Subjects listed include Coe College, Cornell College, Mt. Mercy College, Sacred Heart Convent, Greene's Opera House, Billy Sunday, the Cherry Sisters, the Dieman-Bennett Dance of the Hemispheres, retail trade, department stores, Jane Boyd (founder of the Cedar Rapids Community House), parks, area churches, and floods. All of the interviews are transcribed, and each includes a photograph of the interviewee.

Shenandoah Public Library's oral history collection consists of 40 interviews, 19 of which are with women. Although none are transcribed, there is a short summary of topics for each interview. The women interviewed include several who were involved in KMA radio or who described listening to KMA's homemaker programming such as Kitchen Klatter. Other topics include 4-H Club, Lawrence Welk's performance at a 1932 Armory Dance, managing a traveling concession stand, the history of the library, Chautauquas, service clubs, churches, and café experiences.

The Fayette County Historical Consortium conducted an IHB-supported project interviewing six women and four men about "The Way We Were" in Fayette County, 1900-present. Project organizers attempted to represent diverse backgrounds, ethnic groups, and areas of the county in the interviews, and asked questions about family, home, social events, school, church, farming, employment, politics, and historical events. Transcripts, an abstract, and a photograph of the interviewee are available for each interview. The project is located at the Fayette County Historical Center in West Union.

Two small towns in Iowa have sizable collections about which little information is available. The Greene Public Library 
houses 68 interviews, 37 of which are with women. Approximately 10 of the interviews are transcribed. Topics discussed are unavailable. Forty-three oral history interviews are held by the Mt. Ayr Public Library. Sixteen women were interviewed, discussing topics such as Bohemian customs and festivals, education, "early times," and the opera house. None of the interviews are transcribed.

Two other small collections deserve mention. The Dubuque County Historical Society holds a collection of approximately 30 interviews, but only three are with women: a teacher, a department store salesperson, and Anna B. Lawther, who described her work in the suffrage movement. Six women and six men were interviewed for a project organized by the Akron Public Library. Women interviewed include a piano teacher and choir director, a farm woman known for her gardens, one who participated in Chautauquas, another whose farm was often affected by spring floods, and several discussing community and club activities. None of the interviews in either collection are transcribed.

THESE ORAL HISTORY COLLECTIONS are valuable resources for Iowa history researchers and the public at large. There are at least forty oral history collections in Iowa, extending geographically from Muscatine to Sioux City. Those collections contain more than 1,500 interviews with women covering many aspects of women's experience in Iowa in the twentieth century. In addition to enriching the research of individual scholars, these collections - and more that were undoubtedly missed could bring the historical experience of everyday people into classrooms at all educational levels. They could also enliven public history programs, from museum exhibits to reader's theater presentations and a variety of other creative uses.

Yet most of these collections remain virtually untapped. One can hope that those who are responsible for planning and funding oral history projects in the future will also plan to make the interviews accessible, so that the insights they contain can benefit more than just the people engaged in the projects. Of the forty collections described in this survey (and summarized in the following table), only about half are transcribed, and less 
than one-fourth are indexed. Without indexes or transcripts that enable them to select appropriate interviews to consult and then to skim particular interviews to find the areas that are most applicable to their study, researchers must spend many hours listening to interviews that may or may not be useful to them. Typically, researchers who wish to include oral sources in their research conduct the interviews themselves. They will undoubtedly continue to do so. But by consulting properly maintained oral history collections, they could add many more voices to their stories. The thousands of interviews from a multitude of perspectives in collections across Iowa could potentiallyespecially in the hands of capable and creative researchersenrich and broaden our understanding of the past.

\section{ORAL HISTORY INTERVIEWS WITH WOMEN: A SURVEY OF COLLECTIONS IN IOWA}

\begin{tabular}{||l|l|c|c||}
\hline LOCATION & \multicolumn{1}{|c||}{ DESCRIPTION } & ACCESS & $\begin{array}{c}\text { \# OF } \\
\text { WOMEN } \\
\text { /TOTAL \# }\end{array}$ \\
\hline Akron Public Library & variety & A & $6 / 12$ \\
\hline $\begin{array}{l}\text { Amana } \\
\text { Heritage Museum }\end{array}$ & $\begin{array}{l}\text { Amana heritage, } \\
\text { Communal } \\
\text { Change of 1932 }\end{array}$ & T, I & $\begin{array}{c}\text { "many" } \\
/ 150\end{array}$ \\
\hline $\begin{array}{l}\text { Ames - Parks } \\
\text { State University }\end{array}$ & $\begin{array}{l}\text { 1) faculty, admin- } \\
\text { istrators, alumni } \\
\text { interviewed about } \\
\text { ISU history }\end{array}$ & T, A & $10 / 184$ \\
& $\begin{array}{l}\text { 2) Iowa women } \\
\text { legislators }\end{array}$ & T, I & $45 / 45$ \\
\hline $\begin{array}{l}\text { Cedar Falls } \\
\text { Historical Society }\end{array}$ & variety & T, A & $\begin{array}{l}50-60 \\
/ 200+\end{array}$ \\
\hline $\begin{array}{l}\text { Cedar Rapids } \\
\text { Public Library }\end{array}$ & variety & T, A, I, C & $37 / 86$ \\
\hline
\end{tabular}

1. $T=$ transcribed, $A=$ abstract, $I=$ indexed, $C=$ computer catalogue, $E=e d i t e d$ compilation, $\mathrm{V}=$ videotaped. 


\begin{tabular}{|c|c|c|c|}
\hline LOCATION & DESCRIPTION & ACCESS & $\begin{array}{c}\text { \# OF } \\
\text { WOMEN } \\
\text { /TOTAL \# }\end{array}$ \\
\hline $\begin{array}{l}\text { Clarinda-Nodaway } \\
\text { Valley Museum }\end{array}$ & $\begin{array}{l}\text { African-American } \\
\text { heritage }\end{array}$ & & $22 / 60$ \\
\hline $\begin{array}{l}\text { Davenport } \\
\text { Public Library }\end{array}$ & $\begin{array}{l}\text { Annie Witten- } \\
\text { meyer Home }\end{array}$ & & ongoing \\
\hline $\begin{array}{l}\text { Davenport- } \\
\text { Putnam Museum }\end{array}$ & $\begin{array}{l}\text { 1) Music in the } \\
\text { Quad Cities } \\
\text { 2) Eagle Sign } \\
\text { Company }\end{array}$ & $\begin{array}{l}\mathrm{T}, \mathrm{A} \\
\mathrm{T}, \mathrm{A}\end{array}$ & $\begin{array}{c}14 / 52 \\
2 / ?\end{array}$ \\
\hline $\begin{array}{l}\text { Des Moines } \\
\text { Public Library }\end{array}$ & variety & $\mathrm{T}, \mathrm{A}, \mathrm{I}, \mathrm{C}$ & $31 / 82$ \\
\hline $\begin{array}{l}\text { Des Moines- } \\
\text { Grand View } \\
\text { College Library }\end{array}$ & $\begin{array}{l}\text { Arab-American } \\
\text { immigrants of } \\
\text { central lowa }\end{array}$ & $\mathrm{T}, \mathrm{I}, \mathrm{E}$ & $8 / 20$ \\
\hline $\begin{array}{l}\text { Des Moines- } \\
\text { Italian American } \\
\text { Cultural Center }\end{array}$ & $\begin{array}{l}\text { Italian heri- } \\
\text { tage/immigrants }\end{array}$ & & ongoing \\
\hline $\begin{array}{l}\text { Dubuque County } \\
\text { Historical Society }\end{array}$ & variety & A & $3 / 30$ \\
\hline $\begin{array}{l}\text { Dubuque-Research } \\
\text { Center for Dubuque } \\
\text { Area History }\end{array}$ & $\begin{array}{l}\text { 1) working women } \\
\text { of Dubuque } \\
\text { 2) Great Depres- } \\
\text { sion/New Deal }\end{array}$ & $\mathrm{E}$ & $\begin{array}{l}22 / 22 \\
20 / ?\end{array}$ \\
\hline $\begin{array}{l}\text { Elk Horn-Danish } \\
\text { Immigrant Museum }\end{array}$ & Danish heritage & A & $57 / ?$ \\
\hline $\begin{array}{l}\text { Fort Madison } \\
\text { Public Library }\end{array}$ & $\begin{array}{l}\text { African-American, } \\
\text { German, Latino } \\
\text { heritage }\end{array}$ & & ongoing \\
\hline Greene Public Library & variety & some $\mathrm{T}$ & $37 / 68$ \\
\hline Grinnell College & Jewish heritage & $1 / 2 \mathrm{~T}$ & $79 / 121$ \\
\hline
\end{tabular}




\begin{tabular}{|c|c|c|c|}
\hline LOCATION & DESCRIPTION & ACCESS & $\begin{array}{c}\text { \# OF } \\
\text { WOMEN } \\
\text { /TOTAL \# }\end{array}$ \\
\hline $\begin{array}{l}\text { Grinnell- } \\
\text { Stewart Library }\end{array}$ & $\begin{array}{l}\text { Great Depression } \\
\text { and World War II }\end{array}$ & $\mathrm{T}$ & $9 / 20$ \\
\hline $\begin{array}{l}\text { Iowa City- } \\
\text { State Historical } \\
\text { Society of Iowa }\end{array}$ & $\begin{array}{l}\text { Iowa Labor His- } \\
\text { tory Oral Project }\end{array}$ & $\mathrm{T}, \mathrm{A}, \mathrm{I}, \mathrm{E}$ & $\begin{array}{l}\text { c. } 125 \\
/ 1,000+\end{array}$ \\
\hline $\begin{array}{l}\text { Iowa City - } \\
\text { State Historical } \\
\text { Society of Iowa }\end{array}$ & $\begin{array}{l}\text { rural life, home- } \\
\text { makers, WWII } \\
\text { homefront, misc. }\end{array}$ & $\mathrm{T}, \mathrm{I}$ & $406 / 756$ \\
\hline $\begin{array}{l}\text { Iowa City - } \\
\text { University of Iowa } \\
\text { Affiliated Programs } \\
\text { Clearinghouse }\end{array}$ & $\begin{array}{l}\text { former residents of } \\
\text { state institutions at } \\
\text { Woodward and } \\
\text { Glenwood }\end{array}$ & $\mathrm{T}$ & $4 / 12$ \\
\hline $\begin{array}{l}\text { Iowa City- } \\
\text { University of Iowa } \\
\text { Library, Special } \\
\text { Collections }\end{array}$ & $\begin{array}{l}\text { university admin- } \\
\text { istrators and fac- } \\
\text { ulty, university } \\
\text { history }\end{array}$ & $\mathrm{T}$ & $6 / 46$ \\
\hline $\begin{array}{l}\text { Iowa City - } \\
\text { University of Iowa } \\
\text { Women's Archives }\end{array}$ & $\begin{array}{l}\text { Iowa women } \\
\text { legislators }\end{array}$ & T, I & $45 / 45$ \\
\hline $\begin{array}{l}\text { Laurens } \\
\text { Public Library }\end{array}$ & $\begin{array}{l}\text { Laurens business } \\
\text { and industry }\end{array}$ & & ongoing \\
\hline $\begin{array}{l}\text { Mount Pleasant- } \\
\text { Midwest Old Thresh- } \\
\text { ers Museum of Rep- } \\
\text { ertoire Americana }\end{array}$ & $\begin{array}{l}\text { tent, folk, and } \\
\text { repertory theatre } \\
\text { players, } 1900-1940\end{array}$ & V & $? / 40$ \\
\hline $\begin{array}{l}\text { Mt. Ayr } \\
\text { Public Library }\end{array}$ & variety & & $16 / 43$ \\
\hline $\begin{array}{l}\text { Muscatine-Musser } \\
\text { Public Library }\end{array}$ & variety & A & $49 / 125$ \\
\hline $\begin{array}{l}\text { Ottumwa-Wapello } \\
\text { County Museum }\end{array}$ & $\begin{array}{l}\text { Naval Air Base, } \\
\text { World War II }\end{array}$ & & ongoing \\
\hline Perry Public Library & variety & & $3 / 6$ \\
\hline
\end{tabular}




\begin{tabular}{|c|c|c|c|}
\hline LOCATION & DESCRIPTION & ACCESS & $\begin{array}{c}\text { \# OF } \\
\text { WOMEN } \\
\text { /TOTAL \# }\end{array}$ \\
\hline $\begin{array}{l}\text { Pocahontas } \\
\text { Public Library }\end{array}$ & $\begin{array}{l}\text { Main Street } \\
\text { Pocahontas }\end{array}$ & $\mathrm{T}$ & $3 / 10$ \\
\hline $\begin{array}{l}\text { Red Oak } \\
\text { Public Library }\end{array}$ & $\begin{array}{l}\text { country schools in } \\
\text { Montgomery County }\end{array}$ & & $33 / 41$ \\
\hline Rolfe Public Library & $\begin{array}{l}\text { transportation, } \\
\text { variety }\end{array}$ & $\mathrm{T}$ & $51 / 100$ \\
\hline $\begin{array}{l}\text { Sheldon } \\
\text { Public Library }\end{array}$ & $\begin{array}{l}\text { one-room } \\
\text { country schools }\end{array}$ & & $41 / 64$ \\
\hline $\begin{array}{l}\text { Shenandoah } \\
\text { Public Library }\end{array}$ & variety & A & $19 / 40$ \\
\hline $\begin{array}{l}\text { Sioux Center } \\
\text { Public Library }\end{array}$ & variety & & $41 / 90$ \\
\hline $\begin{array}{l}\text { Sioux City } \\
\text { Public Museum } \\
\end{array}$ & variety & $\mathrm{T}, \mathrm{A}, \mathrm{I}$ & $\begin{array}{l}\text { c. } 180 \\
/ 500\end{array}$ \\
\hline $\begin{array}{l}\text { South Tama High } \\
\text { School Media Center }\end{array}$ & $\begin{array}{l}\text { Mesquakie } \\
\text { Elders }\end{array}$ & $\mathrm{T}$ & ongoing \\
\hline Vinton Public Library & $\begin{array}{l}\text { women in } \\
\text { Benton County }\end{array}$ & T, E & $10 / 10$ \\
\hline $\begin{array}{l}\text { Waterloo- } \\
\text { Grout Museum }\end{array}$ & $\begin{array}{l}\text { industry and agri- } \\
\text { culture (Silos and } \\
\text { Smokestakes oral } \\
\text { history project) }\end{array}$ & & ongoing \\
\hline $\begin{array}{l}\text { West Union, } \\
\text { Fayette County } \\
\text { Historical Center }\end{array}$ & variety & T, A & ongoing \\
\hline
\end{tabular}


Copyright of Annals of Iowa is the property of State of Iowa, by \& through the State Historical Society of Iowa and its content may not be copied or emailed to multiple sites or posted to a listserv without the copyright holder's express written permission. However, users may print, download, or email articles for individual use. 